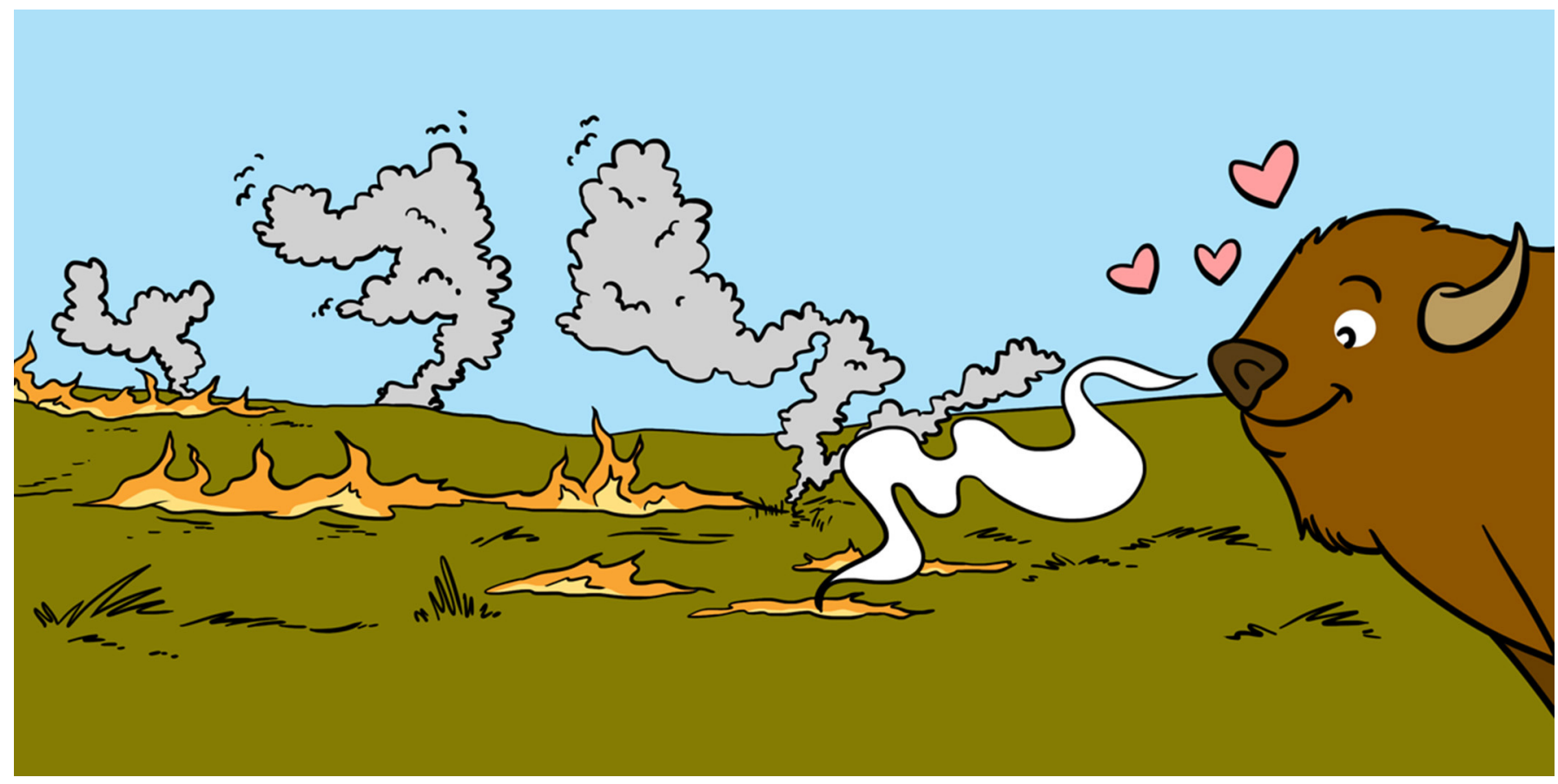

\title{
EATING WHILE THE EATING'S GOOD: HOW FIRE CREATES A MAGNET FOR GRAZING ANIMALS
}

\section{Sherry A. Leis ${ }^{1 *}$ and Carol E. Baldwin ${ }^{2,3}$}

${ }^{1}$ Heartland Inventory and Monitoring Network, National Park Service, Republic, MO, United States

${ }^{2}$ Agriculture, Natural Resources, and Community Vitality, Kansas State University, Manhattan, KS, United States

${ }^{3}$ Great Plains Fire Science Exchange, Manhattan, KS, United States

\section{YOUNG REVIEWERS:} HEADWATERS ACADEMY 8TH GRADE STUDENTS AGES: $13-14$ SKETCHY SCHOOL AGES: 9-14
Tallgrass prairie is disappearing because farming and development have replaced it. This ecosystem is home to a unique group of plants, animals, and microbial life. The processes of fire, grazing by animals, and drought are important to the tallgrass prairie. They can influence each other and prairie life. For example, pyric-herbivory is the interaction of fire and grazing on the landscape. Burned areas attract herbivores (plant eaters) like a magnet. After fires, plant growth is nutritious and easy to find. Herbivores prefer grazing recently burned areas, creating patches of different habitats that support many other wildlife species, too. You can see pyric-herbivory in action at the Tallgrass Prairie National Preserve, where fire, cattle, and bison are a part of the preserve's management team! Healthy tallgrass prairie needs both fire and grazing. 


\section{ECOLOGICAL} DISTURBANCE

A short-term event or process that may cause the death of organisms or change the environment temporarily. Examples include drought, grazing, and fire, but not plowing for crop production.

\section{Figure 1}

Map of tallgrass prairie prior to settlement by non-indigenous peoples (circa 1770). Less than $10 \%$ of this area remains as prairie today. Image used with permission from The Tallgrass Prairie Center, Cedar Falls, Iowa.

\section{WHAT IS PRAIRIE?}

Tallgrass prairie once covered much of central North America (Figure 1) [1]. Unfortunately, more than $90 \%$ of the prairie has been lost to cropland and development. We study the tallgrass prairie because of its important features and unique species. The prairie is fascinating and exciting, but when many people see a prairie for the first time, they only see grass. At first, the landscape may look empty and uninteresting but, as you look closer, an immense variety of life comes into focus. There are many different plant species, including grasses, wildflowers, sedges, and shrubs. Many of the plants are grasses like big bluestem, little bluestem, switchgrass, and Indiangrass. Wildflowers, like leadplant, heath aster, sunflowers, and milkweeds, are also important plants. Healthy prairies have many kinds of plants, but very few trees. The mixture of plants helps to create many habitats for wildlife. Deer, greater prairie-chickens, quail, grasshoppers, bees, and coyotes all depend on the tallgrass prairie. Bison no longer roam free in the tallgrass prairie, but they do live in ranches and parks, like the Tallgrass Prairie National Preserve in Kansas.

The prairie is always changing because of ecological disturbances. Ecological disturbances are short-term events that change the plants, soil, water, or other organisms in an area for a short time. Grazing, fire, and drought (lack of rain) are examples of ecological disturbances than can often be beneficial [2]. The removal of grass leaves by grazing or fire is an example of a change that lasts for a short time (Figure 2). Ecological disturbances such as fire and grazing prevent tree growth while stimulating the germination and flowering of other plants and

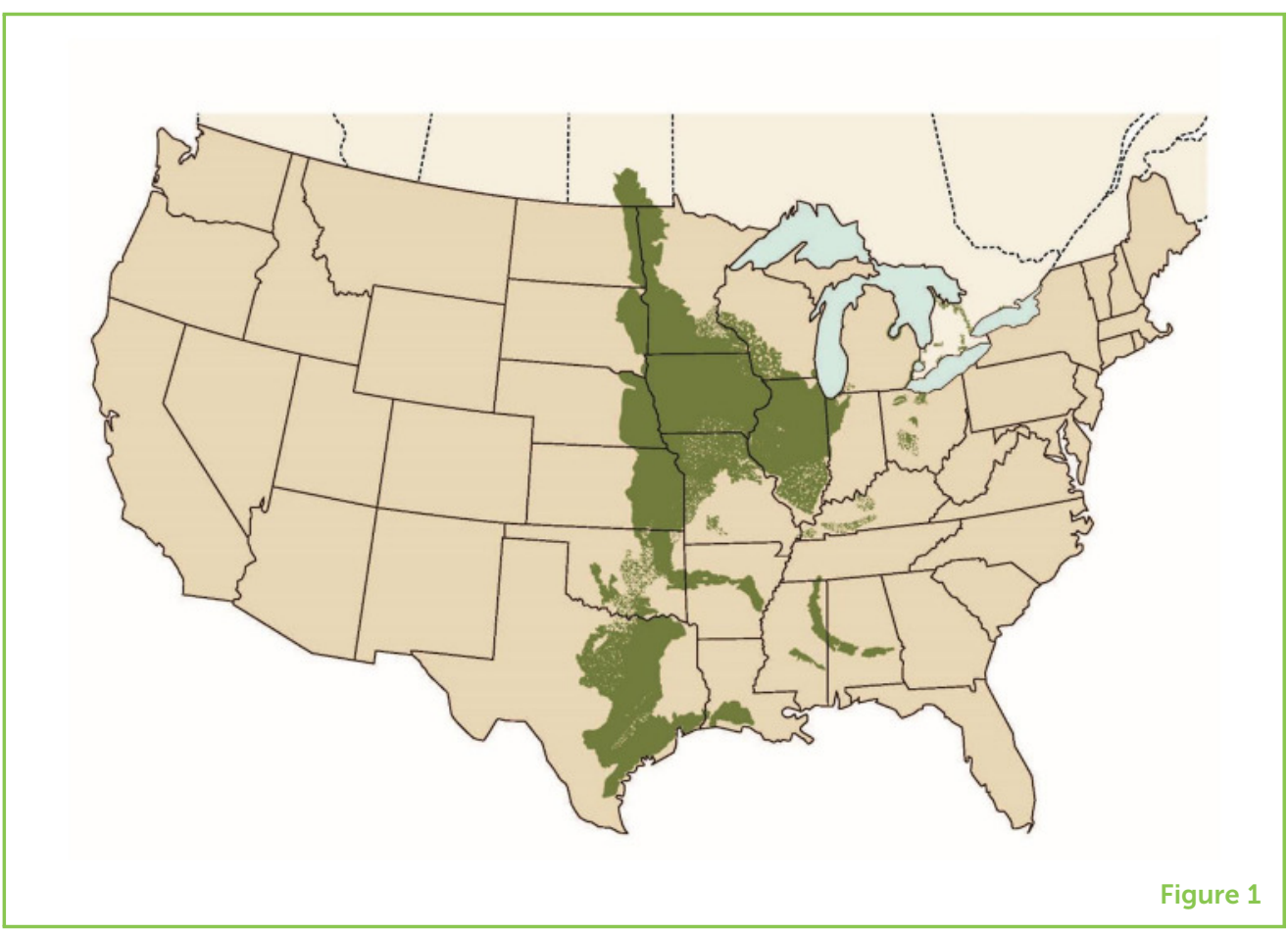


Figure 2

A prescribed burn at the Tallgrass Prairie National Preserve, Strong City, Kansas. The inset shows a closeup of the recently burned area. A grass blade (inside the hoop) began to emerge within a few days after the prescribed burn. Photo credit: Heartland Inventory and Monitoring Network, National Park Service.

\section{ECOSYSTEM}

The living and non-living parts of an area and their connections. Plants, animals, and other organisms interact with soil, rocks, water, light, and other parts of the landscape to survive.

\section{PYRIC-HERBIVORY}

The interaction of fire and grazing. Herbivores tend to graze in recently burned areas rather than unburned areas. The attraction seems to be stronger in moist grassland like tallgrass prairie.

\section{HERBIVORE}

An organism that primarily eats plants.

\section{STANDING DEAD}

Above-ground plant stems that remain vertical even after they die.

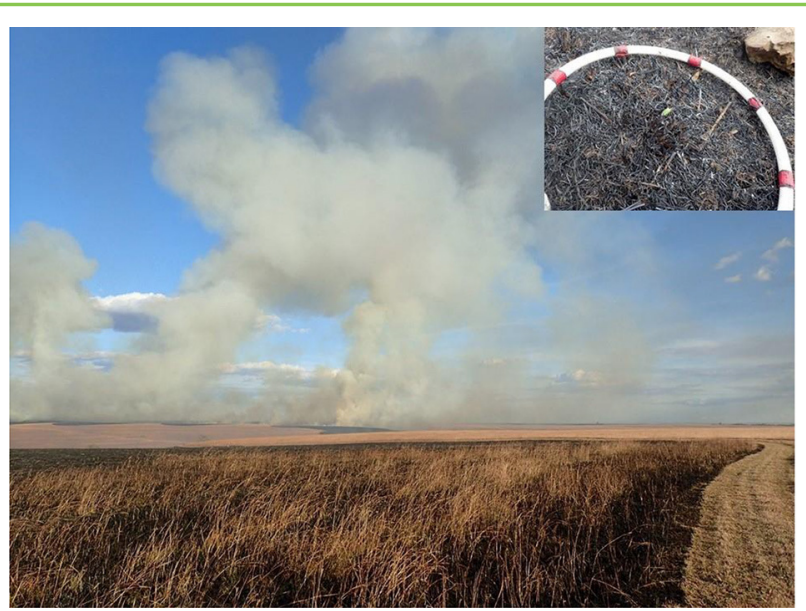

Figure 2

the cycling of nutrients through the ecosystem. Prairies need these ecological disturbances to remain healthy.

\section{FIRE AND GRAZING ARE PRAIRIE PARTNERS}

The attraction between fire and grazing is very strong [3]. This attraction is called pyric-herbivory. For example, cattle spend about $70 \%$ of their time grazing recently burned areas instead of unburned areas. The plants that regrow after a fire often have more key nutrients than the plants in unburned areas have. Herbivores can sense the best-tasting, highest-nutrition food that is also easy to munch on.

The cycle of burning and grazing progresses through the seasons. Tall leaves and stems from the previous year (called standing dead) shade new spring growth and poke the animals' noses when they eat. Fire removes the standing dead, making the fresh growth easier to find. Burning reduces the shade from standing dead plants, which allows more efficient regrowth. Pyric-herbivory creates patches of short, burned-grazed plants next to patches of tall plants that are unburned and ungrazed. As fires are applied to various areas of the prairie, grazing shifts to newly burned patches. Areas that were previously burned and heavily grazed are left unburned, allowing the plants to regrow and rest (Figure 3).

The number of species that can live in a prairie is greatest when there are many habitat types available. Over time, pyric-herbivory provides a variety of habitats across the landscape, such as grasses of different heights, small patches of bare soil, and deep layers of old vegetation. For example, both killdeer and deer mouse are species that prefer bare ground in their habitats [3,4]. Killdeer nest right on the bare soil and deer mice forage in open areas. Recently burned and grazed areas are important habitats for these animals. Henslow's sparrows and cotton 
Figure 3

Photos from the Tallgrass Prairie National Preserve in 2009. (A) Tallgrass prairie burned in the prior month.

Vegetation is short and relatively even in height, due to cattle grazing in the burned area. The white board shows the height of the plants, with black marks indicating $25 \mathrm{~cm}$ increments. Photos were taken 3 meters from the white board.

(B) Tallgrass prairie burned 2 years prior. Vegetation is taller and more variable as it begins to recover from grazing and burning.

\section{LITTER}

Dead plant material laying on the soil surface.
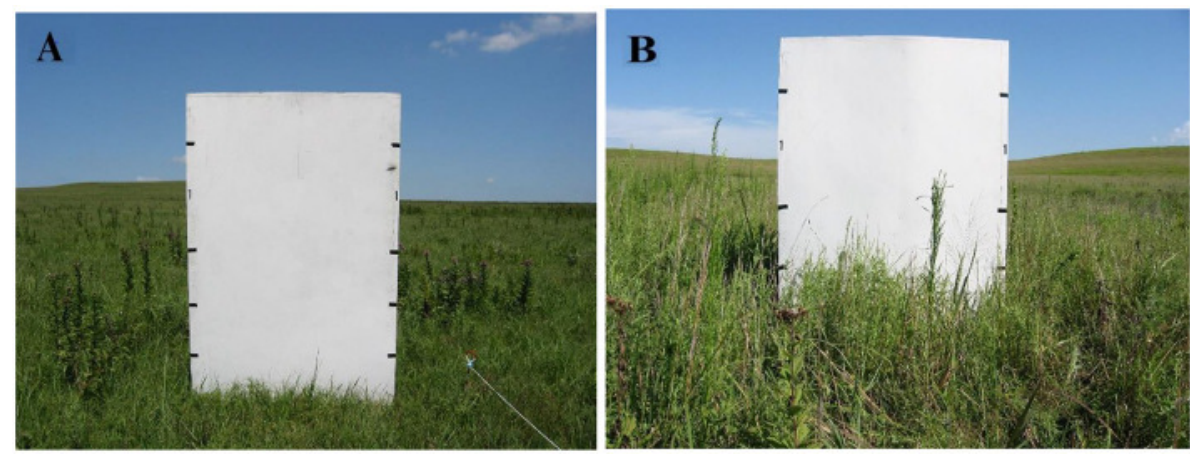

Figure 3

rats, on the other hand, prefer areas with dense plants and litter. Litter is dead plant matter laying on the soil. Areas that have not been burned or grazed for a few years are ideal for these animals. Some animals, like greater prairie-chickens and quail, need more than one type of habitat, even during a single year. These birds need patches of short regrowth, bare ground, and tall grass with litter on the surface, all within their home range. Pyric-herbivory can create the patchy habitat that these prairie birds need.

Greater prairie-chickens are an example of an animal that is vanishing with the tallgrass prairie. Let us look further at their habitat needs. Early in the spring, male prairie-chickens "dance" to attract females. Mating dances occur in short grass or on bare ground, for maximum visibility. After mating, female prairie-chickens look for patches of unburned grass with dense litter to build nests. Tall plants and litter in unburned areas also conceal the hens and their chicks from predators like hawks and coyotes. As the tennis ball-sized chicks grow and begin to forage for food, they need areas that have lots of insects to eat and overhead cover to protect them from predators. The chicks are too small to move easily through the thick litter around the nest. That is why the burned areas are so important. Rapid plant growth after fire (a few weeks is all it takes) provides flowers and seeds that attract insects. Growing plant leaves provide cover, but chicks can move easily without litter blocking the way. Chicks can also find sunshine in burned areas when they need to dry off and warm up. Unburned areas are also valuable for winter refuge. On cold days, abundant litter and seeds for food help to keep the chickens warm. Healthy greater prairie-chicken populations need all these habitat types.

\section{THE FIRE-GRAZING INTERACTION IN ACTION}

You can see pyric-herbivory at the Tallgrass Prairie National Preserve in Kansas, USA. The preserve protects a remnant of the tallgrass prairie ecosystem and explains the local ranching history. Staff use pyric-herbivory to protect the prairie and to tell the ranching story. Historically, ranchers burned the Kansas prairie before spring cattle 
drives. In the 1970s, burns shifted to earlier in the spring and cattle numbers increased. That new system created a more homogenous habitat type, meaning that the vegetation structure during the bird nesting season was very short and even like a lawn and some habitat types were missing. Later after cattle were sent to market, the plants grew taller and thicker, but evenly across the prairie.

In 2006, preserve managers again changed how fire and grazing were used. They began using pyric-herbivory to create a patchier prairie, instead of burning the whole preserve at once. Cattle and bison could then choose between grazing burned or unburned areas in their respective pastures. Researchers then observed the prairie plants and birds to see what changes occurred. Because some areas could now recover from grazing, bare ground decreased overall [5]. Bare ground was still greater in recently burned patches than in unburned patches. Pyric-herbivory led to a more balanced mix of habitat types.

Wildlife responded to these changes, too. Bird species that favored bare ground declined a bit, while birds that preferred denser vegetation increased. This patchy system also favored birds that are tallgrass prairie specialists instead of generalists [6]. Generalists are species that can live in many ecosystems. The increase in tallgrass prairie specialists is important because grassland-specialist birds are in decline in the USA. Providing more diverse habitat at the preserve helps grassland bird populations survive.

Pyric-herbivory also helps the land by decreasing the need for fences. Herbivores stay in the intended area because of their attraction to burned areas. When animals can choose what they graze, they select from a range of plants to meet their nutritional needs. The herbivores will move as they seek new burned areas with nutritious forage. Although fences can keep animals in designated areas, they are expensive and can interfere with wildlife movement. However, pyric-herbivory may not be a good fit for all prairies. It may not work well when the number of herbivores is too high or too low, or in very small prairies. Pyric-herbivory also functions differently in dryer climates. Fire is challenging to implement in some urban prairies, or those close to busy roads or smoke-sensitive businesses.

\section{A PRESCRIPTON FOR FIRE}

Are you wondering how the fires are started? Wildfires are unplanned,

\section{PRESCRIBED BURN}

Fires that are planned and ignited by humans; used for land management in natural areas. lack objectives, and may be started by lightning, powerlines, or accidentally set by humans. Prescribed burns are different from wildfires because they are planned and purposeful. Great Plains Tribal Nations managed prairies with fire long before Europeans arrived [7]. Today, land managers continue to use prescribed burns to manage prairies. 
Managers use prescribed fire to make the prairie ecosystem healthier. They also use a plan of treatment, called a burn plan, that is much like a medical prescription. The burn plan states the objectives, like improving wildlife habitat or the quality of plants available for animals to eat, and explains where and how the fire treatment will take place and what firebreaks will be used. Firebreaks are used to stop fire from crossing into unintended areas. For example, recently burned areas, roads, trails, streams, bare areas, and grazed areas can all stop fire. Burn plans also include lists of safe weather conditions, trained crews, and equipment.

\section{MORE TO LEARN}

There is still much to learn about how animals and fire affect each other in the prairie. Pyric-herbivory may work differently in different prairie types, for example. We know that herbivores respond less intensely to burned areas in dryer ecosystems. The response of some plants to pyric-herbivory is also unknown. Underground, the soil is teeming with organisms about which we know very little, including their response to fire. You can become a scientist who uncovers new facts about the tallgrass prairie. You could also become a land manager who discovers new techniques to conserve the prairie. These are important jobs because they help to protect the prairie for the many organisms that call it home. Scientists and managers share what they have learned about prairies to inspire more people to protect these important places for the benefit of all living creatures including humans.

\section{ACKNOWLEDGMENTS}

We are grateful to the Tallgrass Prairie National Preserve for access and support. We are also grateful for the support and knowledge exchange of the Patch Burn Grazing Community of Practice and the astute student reviewers of this manuscript. This work was funded by the National Park Service, Kansas State University, and The Joint Fire Science Program.

\section{REFERENCES}

1. Sampson, F., and Knopf, F. 1994. Prairie conservation in North America. Bioscience 44:414-8.

2. Knapp, A. K., Briggs J. M., Hartnett D. C., and Collins S. L. (eds.). 1998. Grassland Dynamics: Long-Term Ecological Research in Tallgrass Prairie. Oxford: Oxford University Press.

3. Fuhlendorf, S. D., Harrell, W. C., and Engle, D. M. 2006. Should heterogeneity be the basis for conservation? Grassland bird response to fire and grazing. Ecol. Appl. 16:1706-16. doi: 10.1890/1051-0761(2006)016[1706:shbtbf]2.0.co;2 
4. Fuhlendorf, S. D., Townsend, D. E., Elmore, R. D., and Engle, D. M. 2010. Pyric-herbivory to promote rangeland heterogeneity: evidence from small mammal communities. Rangel. Ecol. Manag. 63:670-8. doi: 10.2111/REM-D10-00044.1

5. Leis, S. A., and Morrison, L. W. 2018. Long-Term Trends in Vegetation and Management Intensity: Tallgrass Prairie National Preserve 1995-2014. Natural Resource Report NPS/HTLN/NRR--2018/1582. Fort Collins, CO: National Park Service.

6. Peitz, D. G., and Kull, K. A. 2020. Bird Community Monitoring at Tallgrass Prairie National Preserve, Kansas: Status Report 2001 -2018. Natural Resource Report. NPS/HTLN/NRR--2020/2072. Fort Collins, CO: National Park Service.

7. Pyne, S. J. 2017. The Great Plains: A Fire Survey. Tuscon: The University of Arizona Press.

SUBMITTED: 28 October 2020; ACCEPTED: 28 October 2021; PUBLISHED ONLINE: 01 December 2021.

EDITED BY: Nina Chambers, National Park Service, United States

CITATION: Leis SA and Baldwin CE (2021) Eating While the Eating's Good: How Fire Creates a Magnet for Grazing Animals. Front. Young Minds 9:622451. doi: 10. 3389/frym.2021.622451

CONFLICT OF INTEREST: The authors declare that the research was conducted in the absence of any commercial or financial relationships that could be construed as a potential conflict of interest.

COPYRIGHT @ 2021 Leis and Baldwin. This is an open-access article distributed under the terms of the Creative Commons Attribution License (CC BY). The use, distribution or reproduction in other forums is permitted, provided the original author(s) and the copyright owner(s) are credited and that the original publication in this journal is cited, in accordance with accepted academic practice. No use, distribution or reproduction is permitted which does not comply with these terms.

\section{YOUNG REVIEWERS}

\section{HEADWATERS ACADEMY 8TH GRADE STUDENTS, AGES: 13-14}

Hi! We are the 8th grade class of 2021 at Headwaters Academy in Bozeman Montana. Bozeman is located just out of Yellowstone National Park. We have a small class of only 16 people, but it is great because we are able to travel together. Our class is very adventurous and athletic, we love spending time outdoors and spend a lot of time on the trails and slopes of the mountains surrounding us.

\section{SKETCHY SCHOOL, AGES: 9-14}

We are from the Sketchy School, created during the pandemic for kids and families wanting to stay safe, and still be social while learning. We laughably call it Sketchy School because we meet in a warehouse and travel in a white van. We are very concerned about our planet, its animals, and how people treat each other. We are 
outdoor enthusiasts and athletes. We love animals. We enjoy reading, baking, writing, singing, dancing, eating, watching TV, and playing video games.

\section{AUTHORS}

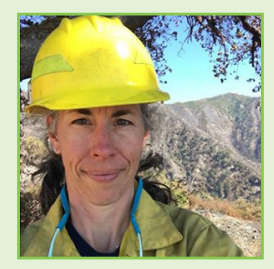

\section{SHERRY A. LEIS}

Sherry Leis is an ecologist with the National Park Service. She specializes in plants and fire ecology with emphasis on grassland ecosystems. Sherry is interested in how disturbances shape grassland communities. She has a master's degree in plant and soil science with emphasis in rangeland ecology and management as well as bachelor's degrees in anthropology and environmental biology. *sherry_leis@nps.gov

\section{CAROL E. BALDWIN}

Carol Baldwin is an extension associate at Kansas State University. She currently leads the Great Plains Fire Science Exchange, one of fifteen networks in the Joint Fire Science Program's national exchange network. Carol works to make science understandable for managers and others who work in grassland management and wildland fire. Carol's degrees are in range management (M.S. and Ph.D.) and production agronomy (B.S.), and she has 17 years of science outreach experience. She has also taught a university course and numerous guest lectures. 